Tribhuvan University Journal

Vol. 33, No. 2: 1-14, December, 2019

Centre for Research, Tribhuvan University,

Kathmandu, Nepal

DOI: https://doi.org/10.3126/tuj.v33i2.33560

\title{
ANALYTICAL STUDY ON FERTILITY STATUS AND SOIL QUALITY INDEX OF SHOREAROBUSTA FOREST, CENTRAL NEPAL
}

\author{
Mahendra Singh Thapa ${ }^{1^{*}}$, Thakur Bhattarai ${ }^{2}$, Ram Prasad \\ Sharma ${ }^{3}$, Baburam K. C and Lila Puri $^{4}$ \\ ${ }^{1}$ Lecturer, Pokhara Campus, Pokhara, Institute of Forestry, TU \\ ${ }^{2}$ Senior Lecturer and Research Fellow, Institute of Future Farming Systems, Central \\ Queensland University, Queensland, Australia \\ ${ }^{3}$ Associate Professor, Pokhara Campus, Pokhara, Institute of Forestry, TU \\ ${ }^{4}$ Assistant Professors, Pokhara Campus, Pokhara, Institute of Forestry, TU \\ *Corresponding author
}

\begin{abstract}
Physiochemical parameters of soil under Shorearobusta forest was estimated to evaluate the soil fertility status and soil quality index in different altitudes of community managed forest of Khairani Municipality Chitwan district Nepal. Altogether 75 soil samples were collected from the forest area at five different depths. Sandy clay loam and sandy loam texture was found in surface and subsurface layer respectively. The mean soil $\mathrm{pH}$ of altitudinal strata was 5.57 which is moderately acidic and showed decreasing trend with increasing soil depths. Average bulk density ranged from 1.14 to 1.30 in all attitudes. Organic carbon varied from 0.30 to $1.30 \%$ and organic matter ranges from 0.52 to $2.23 \%$. The amount of mean available phosphorus seem low to medium rating in these forest strata. Mean exchangeable potassium varied from $61.89 \mathrm{mg} \mathrm{kg}^{-1}$ to 96.02 $\mathrm{mg} \mathrm{kg}^{-1}$ in different altitudes. Most of these soil attributes decreased with the increasing depth. Pearson correlation analysis among the different soil parameters were showed statistically significant at the 0.01 level $(2$ - tailed $)$ and 0.05 levels ( 2 - tailed). One way ANOVA of the studied soil parameters in different altitudes observed that they were statistically significant at 0.05 level $(p \leq 0.05)$. The overall soil fertility status of the Kankali Community Forest is low to medium. An average SQI was found 0.55 (fair) up to $120 \mathrm{~cm}$ depths,slightly decreased with increasing soil depths. Regulation of Leaf litter collection and adoption of appropriate silvicultural operation may help to increase the fertility status and site quality of Kankali community forest.
\end{abstract}

Keywords: total N - available P - SOC - soil texture - bulk density. 


\section{INTRODUCTION}

Forest soil influences the composition of the forest stand and ground cover, rate of tree growth and vigor of natural reproduction. Physiochemical characteristics of soils vary in space and time due to variations in topography, climate, physical and chemical weathering processes, vegetation cover, microbial activities, and several other biotic and abiotic variables. Vegetation plays an important role in soil formation (Chapman \& Reiss 1992) through decomposition of plant tissues for the main source of soil organic matter, which controls the physiochemical characteristics of soil such as $\mathrm{pH}$, water holding capacity, texture and nutrient availability (Johnston 1986). Nutrient supply varies widely among ecosystems (Binkley \& Vitousek 1989), resulting in differences in plant community structure and production (Chapin et al. 1986). Organic matter supplies energy and cell building constituents for most microorganisms (Allison 1973) and is a critical factor in soil fertility (Brady 2000).

The soil quality is a capacity of specific kind of soil to function, within natural or managed landscapes, to sustain plant and animal productivity, maintain or enhance water and air quality, and support human health and habitation (Karlen et al. 1997). Inherent and dynamic soil quality has been used to analyze for productivity of forest ecosystem. The inherent soil quality shows little change over time whereas dynamic soil quality changes with respect to soil management (Larsen \& Pierce 1994). Soil quality assessment is carried out by selecting a set of soil properties which are considered as indicators of soil quality. Soil quality evaluation using both surface and subsurface properties will help to identify the soil properties having maximum influence on soil functions. The present study was undertaken to understand the soil fertility and soil quality status at Kankali community forest of Nepal and tried to correlate macronutrients content of the soils with other soil properties.

\section{MATERIALS AND METHODS}

\section{Study Area}

The Kankali Community Forest (KCF) of the Siwalik zone in Khaireni municipality-4 of Chitwan district, central Nepal was selected for the study (Fig. 1). The altitude of the KCF ranges from $200 \mathrm{~m}$ to $500 \mathrm{~m}$. It comprises fine to medium grained sandstone and gray to greenish gray mudstone rocks of Lower and Middle Siwaliks. The KCF contains dominantly of Shorearobusta with Dalbergiasissoo and other species. The 
maximum and minimum temperature was $31^{\circ} \mathrm{C}$ and $18^{\circ} \mathrm{C}$ respectively while total annual rainfall was $2278 \mathrm{~mm}$ and average relative humidity was $78 \%$.
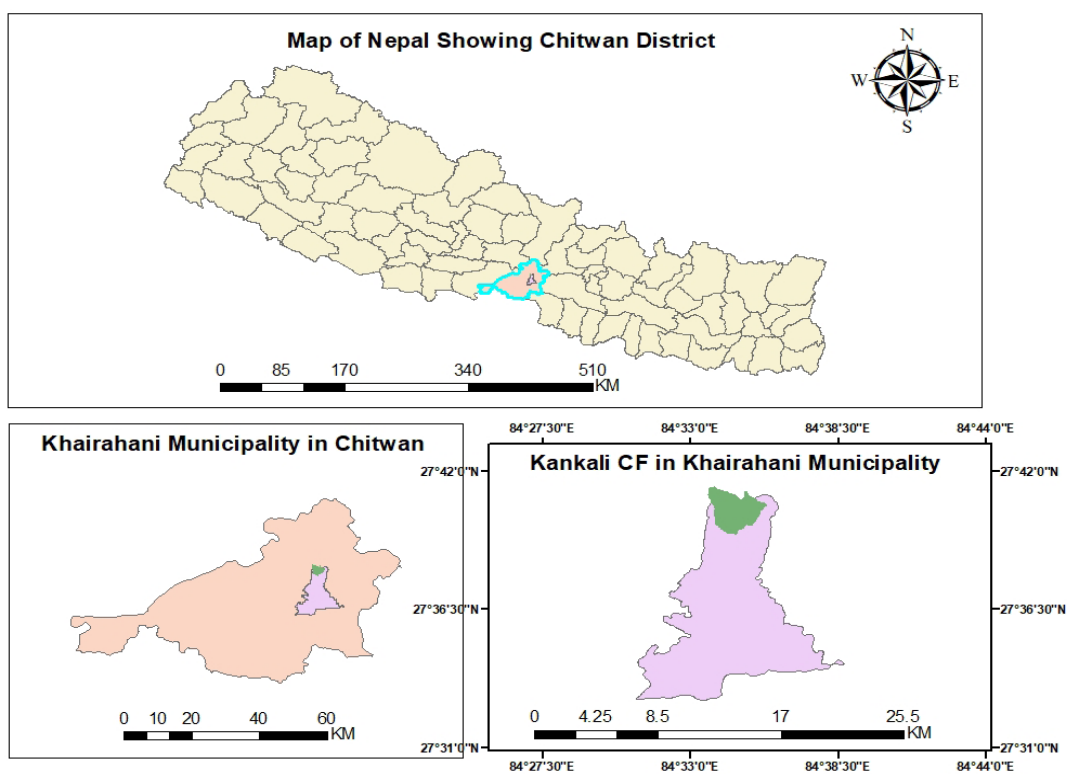

Figure 1: Study area map.

\section{Soil samples collection and analysis}

A total of 75 soil samples (25 soil samples/stratum)were collected from predetermined depths viz. 0-15 cm, $15-30 \mathrm{~cm}, 30-60 \mathrm{~cm}, 60-90$ $\mathrm{cm}$ and 90-120 cm from each altitudinal stratum(201-300 m, 301-400 $\mathrm{m}$ and 401-500 $\mathrm{m})$. The soil $\mathrm{pH}$ was estimated in distilled water $(1: 2.5)$ suspension using a digital pH Meter (Jackson 1967). Organic carbon was estimated using the Walkley and Black, and total nitrogen was determined using Kjedhal method as described by Jackson (1967). Exchangeable $\mathrm{K}$ was determined by the ammonium acetate extracting solution using flame photometer (Jackson 1967). Texture was determined by Bouyoucos hydrometer method (Bouyoucos 1962).

\section{Interpretation of Soil Quality Index}

Soil parameters such as soil texture, soil $\mathrm{pH}$, soil organic matter (SOM), total nitrogen, available phosphorus and exchangeable potassium are used to determine SQI using soil quality rating guide developed by 
Bajracharyaet al. 2006 (Table 1). The individual index values for all the soil properties measured on study area are summed to give a total SQI (Bajracharya et al. 2006):

$$
\mathrm{SQI}=[(\mathrm{a} * \mathrm{RSTC})+(\mathrm{b} * \mathrm{RpH})+(\mathrm{c} * \mathrm{ROM})+(\mathrm{d} * \mathrm{RNPK})]
$$

Where,

RSTC $=$ Ranking for soil textural class,

$\mathrm{RpH}=$ Ranking for soil $\mathrm{pH}$,

$\mathrm{ROM}=$ Ranking for organic matter

RNPK = Ranking for nitrogen, phosphorus and potassium, and

$\mathrm{a}, \mathrm{b}, \mathrm{c}$, and $\mathrm{d}=$ weighting values corresponding to each of the above mentioned four parameters.

Table 1: Soil quality rating guide

\begin{tabular}{llllll}
\hline \multicolumn{1}{c}{ Parameters } & \multicolumn{5}{l}{ Ranking values } \\
\hline & 0.2 & 0.4 & 0.6 & 0.8 & 1 \\
Soil textural class* & $\mathrm{C}, \mathrm{S}$ & $\mathrm{CL}, \mathrm{SC}, \mathrm{SiC}$ & $\mathrm{Si}, \mathrm{LS}$ & $\mathrm{L}, \mathrm{SiL}, \mathrm{SL}$ & $\mathrm{SiCL}, \mathrm{SCL}$ \\
Soil pH & $<4,>8.5$ & 4 to 5 & 5 to 6 & 6 to $6.5 ; 7.5-8.5$ & 6.5 to 7.5 \\
Soil OC \% & $<0.5$ & 0.5 to 1 & 1 to 2 & 2 to 4 & $>4$ \\
Fertility $(\mathrm{N}+\mathrm{P}+\mathrm{K})$ & Low & Mod. Low & Moderate & Mod. High & High \\
SQR $\dagger$ & V. poor & Poor & Fair & Good & Best \\
\hline
\end{tabular}

Source: Bajracharya et al. 2006

${ }^{*} \mathrm{C}=$ clay, $\mathrm{S}=$ sand, $\mathrm{CL}=$ clay loam, $\mathrm{SC}=$ sandy clay, $\mathrm{SiC}=$ silty clay, $\mathrm{Si}=$ silt, $\mathrm{LS}=$ loamy sand, $\mathrm{L}=$ loam, $\mathrm{SiL}=$ silt loam, $\mathrm{SL}=$ sandy loam, $\mathrm{SiCL}=$ silty clay loam, $\mathrm{SCL}=$ sandy clay loam. $\quad \dagger=$ soil quality rating

Bajracharya et al. (2006) has given weighting value of NPK in their equation on the basis of soil quality rating by NARC (1999) from the reference of hill soils of Nepal (Table 2).

Table 2: N, P and K interpretation of hill soil of Nepal

\begin{tabular}{llllll}
\hline \multicolumn{2}{c}{ Total N (\%) } & \multicolumn{2}{c}{ Available P (kg/ha) } & \multicolumn{2}{c}{ Exchangeable K (kg/ha) } \\
Range & level & Range & level & Range & level \\
\hline$<0.1$ & Low & $<31$ & Low & $<110$ & Low \\
$0.1-0.2$ & Medium & $31-55$ & Medium & $110-280$ & Medium \\
$>0.2$ & High & $>55$ & High & $>280$ & High \\
\hline
\end{tabular}

Source: NARC 1999

RESULTS AND DISCUSSIONS 


\section{Soil fertility status based on physical properties}

Altitudinal strata of KCF indicate that soils in general are sandy clay loam (SCL) and sandy loam (SL) texture. At 201-300 m altitude, all the layers of soil have SCL texture with increasing sand percentage and decreasing clay percentage in surface layer. Sandy loam texture in surface layers and SCL texture in deeper subsurface layers are found at 301- 400 $\mathrm{m}$ altitude with slight increasing percentage of sand and clay in subsurface layers. The distribution of texture at 401-500 m altitude in KCF is SL in top layer and SCL in deeper layers. The sand percentage decreased with increasing soil depths. The textures found in all altitudes fall in good and best rating. It means that the textures of this forest can support suitable growth of plants due to nutrients available from finer soil, root respiration and mechanical strength from coarser soil. Bajracharya et al. (2006) reported the similar textures for forest regeneration and high quality trees (Paudel \& Sah 2003). These textures are also very common in the Terai, Siwalik and Doon valley, which support dense S. robusta forests and other valuable timber trees (Shah 1999). This may be due to the similar type of forest vegetation, i.e., S. robusta dominated forest, climate and parent materials.

Higher bulk density (1.27 to $\left.1.33 \mathrm{~g} / \mathrm{cm}^{3}\right)$ shows in the soils at middle altitude in all the depths followed by high altitude (1.15 to $1.25 \mathrm{~g}$ / $\mathrm{cm}^{3}$ ) and the least at lower altitude (1.11 to $\left.1.18 \mathrm{~g} / \mathrm{cm}^{3}\right)$. There is substantial decrease in bulk density in all surface layers due to the addition of humus in the soils and in general, higher the humus lowers the bulk density. The slightly higher bulk density in middle altitude may be due to the presence of regeneration vegetation and steepness of slope. Gautam and Mandal (2013) reported that the bulk density was minimum $\left(1.28 \mathrm{~g} / \mathrm{cm}^{3}\right)$ in the upper layer which increased depth-wise with statistically significant different $(\mathrm{P}<$ $0.001)$ at three different depths $(0-15,15-30$ and 30-45 cm). Ranabhat et al. (2008) reported the bulk density range of Nepalese forest soil from $1.01 \mathrm{~g}$ $\mathrm{cm}^{-3}$ in top layer to $1.47 \mathrm{~g} \mathrm{~cm}^{-3}$ in $80-100 \mathrm{~cm}$ depth with increasing Db with increasing depths.

\section{Soil fertility status based on chemical properties}

Soil reaction is slightly higher i.e. less acidic soils at middle altitude as compared to higher and lower altitudes. It may be due to the presence of acidic parent materials. However, all altitudes show moderately acidic to slightly acidic pH (5.23 to 5.98) in all depths. Overall, soil pH is more acidic in surface layer as compared to subsurface layer. This may be 
due to local environmental factors such as aspect, rainfall, and vegetation composition. These values (4.33-5.26 and 4. 74) are similar as reported by Paudel and Sah (2003) and Kharal et al.(2018)in different $S$. robusta forests. Good $S$. robusta regeneration areas favor slightly acidic soils (Bhatnagar, 1965). The acidic nature of the soil in this site may be attributed to the high rainfall, which is sufficient to leach basic cations from the surface horizons of the soils.

Organic carbon varies from 0.30 to $1.30 \%$ and organic matter 0.52 to $2.23 \%$ in the soils at different altitudes. The mean organic matter of all layers are observed higher at 301-400 m altitude (1.12\%) and followed by $401-500 \mathrm{~m}(1.09 \%)$ and $201-300 \mathrm{~m}(1.07 \%)$. The rating of the organic matter at KCF falls in low. Organic matter brings favorable changes in terms of the soil air, water holding capacity, structure, porosity, bulk density, color, nutrient storage and availability, cation exchange capacity and the microbial population and their activity (Kononova, 1966).

Table 3: Soil fertility status in different soil layers

\begin{tabular}{|c|c|c|c|c|c|c|c|c|c|c|c|c|}
\hline 言 & 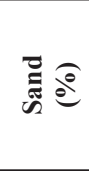 & 흐 & 远 & 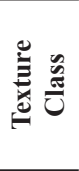 & 官 & 플 & 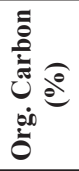 & 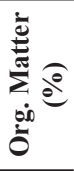 & $\frac{z}{\tilde{c}} \stackrel{0}{e}$ & है & 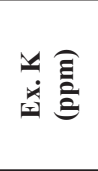 & 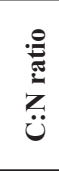 \\
\hline \multicolumn{13}{|c|}{201 - 300 m Altitude } \\
\hline $0-15$ & 57.25 & 18.75 & 24.00 & SCL & 1.11 & 5.45 & 1.28 & 2.19 & 0.20 & 10.75 & 70.10 & 6.51 \\
\hline $15-30$ & 50.50 & 20.50 & 29.00 & SCL & 1.12 & 5.47 & 0.75 & 1.28 & 0.19 & 8.25 & 62.70 & 3.91 \\
\hline $30-60$ & 52.25 & 18.75 & 29.00 & SCL & 1.15 & 5.54 & 0.49 & 0.77 & 0.13 & 4.25 & 61.65 & 3.77 \\
\hline $60-90$ & 52.25 & 16.25 & 31.50 & SCL & 1.14 & 5.53 & 0.33 & 0.56 & 0.10 & 5.00 & 58.35 & 3.30 \\
\hline $90-120$ & 52.25 & 16.25 & 31.50 & SCL & 1.18 & 5.43 & 0.31 & 0.53 & 0.10 & 5.75 & 56.65 & 3.10 \\
\hline Avg. & 52.90 & 18.10 & 29.00 & & 1.14 & 5.48 & 0.62 & 1.07 & 0.16 & 6.80 & 61.89 & 3.69 \\
\hline \multicolumn{13}{|c|}{301 - 400 m Altitude } \\
\hline $0-15$ & 54.00 & 27.00 & 19.00 & SL & 1.27 & 5.69 & 0.64 & 1.09 & 0.16 & 25.75 & 110.10 & 4.07 \\
\hline $15-30$ & 64.00 & 19.50 & 16.50 & SL & 1.28 & 5.64 & 0.74 & 1.28 & 0.13 & 21.00 & 104.35 & 5.80 \\
\hline $30-60$ & 66.50 & 14.50 & 19.00 & SL & 1.32 & 5.78 & 0.70 & 1.20 & 0.14 & 18.75 & 98.25 & 5.09 \\
\hline $60-90$ & 65.00 & 14.50 & 20.50 & SCL & 1.28 & 5.91 & 0.67 & 1.14 & 0.13 & 14.50 & 95.10 & 5.24 \\
\hline $90-120$ & 57.50 & 19.50 & 23.00 & SCL & 1.33 & 5.98 & 0.51 & 0.87 & 0.10 & 11.00 & 72.30 & 4.83 \\
\hline Avg. & 61.40 & 19.00 & 19.60 & & 1.30 & 5.80 & 0.65 & 1.12 & 0.13 & 18.20 & 96.02 & 5.01 \\
\hline \multicolumn{13}{|c|}{401 - 500 m Altitude } \\
\hline $0-15$ & 68.00 & 17.00 & 15.00 & SL & 1.15 & 5.40 & 1.30 & 2.23 & 0.18 & 20.50 & 115.45 & 7.06 \\
\hline $15-30$ & 60.50 & 17.00 & 22.50 & SCL & 1.19 & 5.26 & 0.74 & 1.27 & 0.14 & 10.00 & 73.95 & 5.14 \\
\hline $30-60$ & 60.50 & 19.50 & 20.00 & SCL & 1.21 & 5.23 & 0.53 & 0.90 & 0.13 & 9.50 & 52.55 & 4.17 \\
\hline $60-90$ & 55.50 & 22.00 & 22.50 & SCL & 1.25 & 5.40 & 0.45 & 0.52 & 0.11 & 6.00 & 58.60 & 4.10 \\
\hline $90-120$ & 55.50 & 24.50 & 20.00 & SCL & 1.21 & 5.40 & 0.38 & 0.55 & 0.10 & 5.25 & 66.85 & 3.80 \\
\hline Avg. & 60.00 & 20.00 & 20.00 & & 1.20 & 5.34 & 0.64 & 1.09 & 0.14 & 10.25 & 73.48 & 4.32 \\
\hline
\end{tabular}

Source: Field survey 2016

The lower organic carbon is estimated in this forest as the reason of dominancy of young trees i.e. pole, saplings and very low ground cover by 
herbs and grasses. The main resources of organic carbon are foliage, other fragmented part of the trees and stumps.

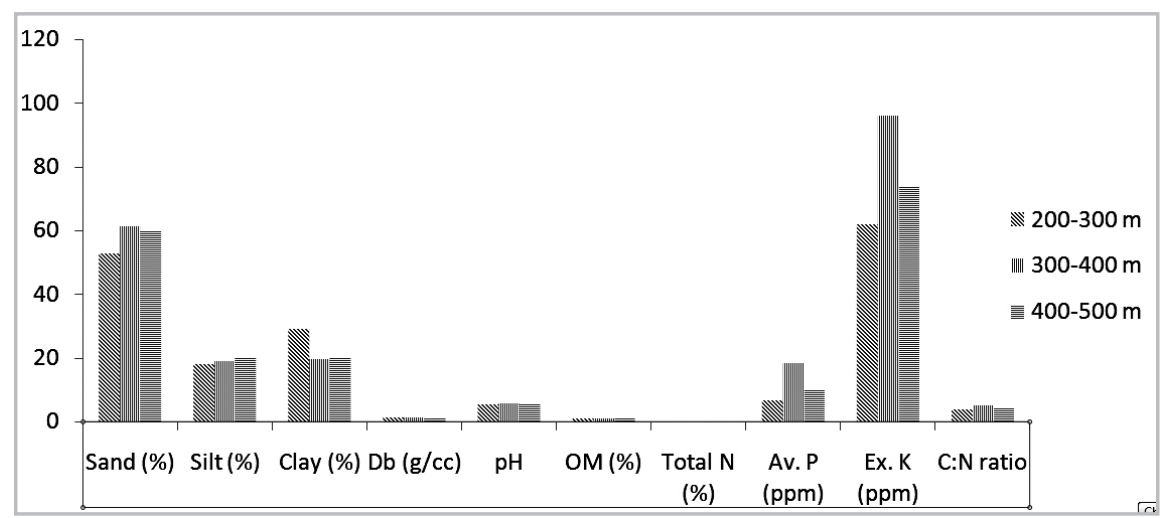

Figure 2: Comparison of soil parameters with respect to altitudes in $\mathrm{KCF}$

The total nitrogen content shows the similar trend as that of the carbon. Higher mean total nitrogen $(0.16 \%)$ is observed at 201-300 maltitude followed by $401-500 \mathrm{~m}(0.14 \%)$ and $301-400 \mathrm{~m}$ altitude $(0.13$ $\%$ ). The total nitrogen of this study found in low to medium rating. This is due to the domination of regenerated tree species, low ground cover, denitrification due to domination of south facing slope and frequent firing. Low to medium rating was reported by Sharma (2013) in the S. robusta dominated forest of Nepal. The total nitrogen levels in Nepal ranged from 0.05 to $0.40 \%$ (LRMP, 1986). Enrichment of soil with nitrogen,improved the soil fertility(Gupta \& Sharma 2009).

An amount of mean available phosphorus at 301-400 m altitude (18.20 mg kg-1) is nearly three times as compared to soils at $201-300 \mathrm{~m}$ altitude (6.80 $\mathrm{mg} \mathrm{kg}^{-1}$ ) and nearly doubled as compared to soils at 401-500 $\mathrm{m}$ altitude (10.25 $\mathrm{mg} \mathrm{kg}^{-1}$ ). The mean available phosphorus seems low to medium rating in these forest strata. Paudel and Sah (2003) reported the 76.64 to $79.29 \mathrm{~kg} /$ ha available phosphorus in pure and mixed S. robusta forests of Nepal. Moderately low to low levels of available phosphorus were reported by LRMP(1986).

Mean exchangeable potassium of different layers is higher in the soils at $301-400 \mathrm{~m}$ altitude $\left(96.02 \mathrm{mg} \mathrm{kg}^{-1}\right)$ followed by $401-500 \mathrm{~m}$ altitude (73.48 $\mathrm{mg} \mathrm{kg}^{-1}$ ) and 201-300 m altitude (61.89 $\left.\mathrm{mg} \mathrm{kg}^{-1}\right)$. Exchangeable potassium is higher in surface layer as compared to subsurface layers. It gradually decreased in deeper layers Exchangeable potassium was found 
higher in surface layer as compared to subsurface layers (Joshi et al., 1999). The exchangeable potassium ranged from 233.86 to $267.73 \mathrm{~kg} / \mathrm{ha}$ was presented by Paudel and Sah (2003).

Table 4: Pearson correlation among soil parameters in KCF

\begin{tabular}{|c|c|c|c|c|c|c|c|c|c|c|}
\hline Parameters & $\begin{array}{l}\text { Sand } \\
(\%)\end{array}$ & $\begin{array}{l}\text { Silt } \\
(\%)\end{array}$ & $\begin{array}{l}\text { Clay } \\
(\%)\end{array}$ & $\begin{array}{c}\mathrm{Db}(\mathrm{g} / \\
\text { cc) }\end{array}$ & pH & $\begin{array}{l}\text { OC } \\
(\%)\end{array}$ & $\begin{array}{l}\text { OM } \\
(\%)\end{array}$ & $\begin{array}{c}\text { Total } \\
\text { N (\%) }\end{array}$ & $\begin{array}{l}\text { Avl. P } \\
\text { (ppm) }\end{array}$ & $\begin{array}{l}\text { Ex. K } \\
\text { (ppm) }\end{array}$ \\
\hline Sand $(\%)$ & 1 & & & & & & & & & \\
\hline Silt (\%) & $-.644 * *$ & 1 & & & & & & & & \\
\hline Clay (\%) & $-.656^{* *}$ & -0.155 & 1 & & & & & & & \\
\hline $\mathrm{BD}(\mathrm{g} / \mathrm{cc})$ & $.575^{* *}$ & -0.244 & $-.502 * *$ & 1 & & & & & & \\
\hline pH & -0.12 & 0.159 & -0.002 & $.422 *$ & 1 & & & & & \\
\hline OC (\%) & 0.122 & 0.028 & -0.186 & -0.147 & 0.052 & 1 & & & & \\
\hline OM (\%) & 0.132 & 0.023 & -0.194 & -0.133 & 0.067 & $.997 * *$ & 1 & & & \\
\hline Total N (\%) & -0.141 & 0.131 & 0.053 & $-.388 *$ & -0.067 & $.813 * *$ & $.813^{* *}$ & 1 & & \\
\hline Avl. P (ppm) & 0.321 & 0.208 & $-.621^{* *}$ & $.410^{*}$ & 0.36 & $.506 * *$ & $.519^{* *}$ & 0.328 & 1 & \\
\hline Ex. K (ppm) & -0.063 & $.363^{*}$ & -0.277 & 0.142 & $.527 * *$ & $.552 * *$ & $.552 * *$ & $.406^{*}$ & $.717 * *$ & 1 \\
\hline C:N ratio & 0.277 & -0.041 & -0.318 & 0.084 & 0.227 & $.879 * *$ & $.883 * *$ & $.482 * *$ & $.573 * *$ & $.600 * *$ \\
\hline
\end{tabular}

** Correlation is significant at the 0.01 level (2-tailed) and * Correlation is significant at the 0.05 level (2-tailed).

The soil parameters are statistically significant at the 0.01 level (2 - tailed) and 0.05 levels ( 2 - tailed) (Table 4). The percentage of sand is negatively correlated with clay percent $(\mathrm{r}=-0.656)$, silt per cent $(\mathrm{r}=-0.664)$, the bulk density is positively correlated with $\mathrm{pH}(\mathrm{r}=0.422)$, available phosphorus $(r=0.410)$, sand $(r=0.575)$ and negatively correlated with clay $(r=0.502)$. The positive correlation $(r=0.527)$ is showed between soil $\mathrm{pH}$ and exchangeable potassium. The organic carbon/organic matter are positively correlated with total nitrogen $(\mathrm{r}=0.813)$, exchangeable potassium $(\mathrm{r}=0.552)$ and $\mathrm{C}: \mathrm{N}$ ratio $(\mathrm{r}=0.879)$. The total nitrogen shows positive correlation with exchangeable potassium $(\mathrm{r}=0.406)$ and $\mathrm{C}: \mathrm{N}$ ratio $(\mathrm{r}=0.482)$. An available phosphorus is correlated positively with exchangeable potassium $(r=0.717), \mathrm{C}: \mathrm{N}$ ratio $(\mathrm{r}=0.573)$ and negatively with clay $(\mathrm{r}=0.621)$. An exchangeable potassium is correlated positively with silt $(\mathrm{r}=0.363)$ and $\mathrm{C}: \mathrm{N}$ ratio $(\mathrm{r}=0.600)$.

The soil parameters are tested through one way ANOVA (Table 5) at 0.05 level $(\mathrm{p}=<0.05)$. The $\mathrm{pH}$ at $201-300 \mathrm{~m}$ altitude is statistically significantly different with the $\mathrm{pH}$ at $301-400 \mathrm{~m}$ altitude with mean 
difference $0.31 *$ (Variance ratio, $\mathrm{F}=11.142$ and $\mathrm{p}=0.004$ ) and similarly, $301-400 \mathrm{~m}$ altitude is significantly different at 401-500 $\mathrm{m}$ altitude with mean difference $0.46 *$ (Variance ratio, $\mathrm{F}=11.142$ and $\mathrm{p}=0.001$ ).

Table 5: Altitude wise least significant difference (LSD) of soil parameters

\begin{tabular}{|c|c|c|c|c|}
\hline $\begin{array}{l}\text { SI. } \\
\text { No. }\end{array}$ & Soil parameter & Strata & $\begin{array}{l}\text { Mean } \\
\text { difference }\end{array}$ & P value \\
\hline \multirow{2}{*}{1} & \multirow{2}{*}{ Soil pH } & 201-300 m Vs 301-400 m & $0.3130 *$ & 0.004 \\
\hline & & $301-400 \mathrm{~m} \mathrm{Vs} 401-500 \mathrm{~m}$ & $0.4610 *$ & 0.001 \\
\hline \multirow{3}{*}{2} & \multirow{3}{*}{ Bulk Density } & $201-300 \mathrm{~m} \mathrm{Vs} 301-400 \mathrm{~m}$ & $0.1540 *$ & 0.001 \\
\hline & & $201-300 \mathrm{~m} \mathrm{Vs} 401-500 \mathrm{~m}$ & $0.0580 *$ & 0.047 \\
\hline & & $301-400 \mathrm{~m}$ Vs $401-500 \mathrm{~m}$ & $0.0960 *$ & 0.002 \\
\hline \multirow{2}{*}{3} & \multirow{2}{*}{ Available Phosphorus } & 201-300 m Vs 301-400 m & $11.400 *$ & 0.001 \\
\hline & & $301-400 \mathrm{~m}$ Vs $401-500 \mathrm{~m}$ & $7.950^{*}$ & 0.006 \\
\hline
\end{tabular}

*Mean difference is significant at the 0.05 level

The significant different is observed in bulk density at 201-300 $\mathrm{m}$ and $301-400 \mathrm{~m}$ altitude with mean difference $0.15 *$ (Variance ratio, $\mathrm{F}=15.599$, $\mathrm{p}=0.001$ ) and $401-500 \mathrm{~m}$ altitude with mean difference $0.06^{*}$ (Variance ratio, $\mathrm{F}=15.599, \mathrm{p}=0.047)$. Significantly different with mean difference $0.10 *$ (Variance ratio, $\mathrm{F}=15.599, \mathrm{p}=0.002$ ) of bulk density at $401-500 \mathrm{~m}$ altitude and 301-400 m altitude is observed. Available phosphorus content in 201-300 $\mathrm{m}$ altitude is significantly different at 301-400 $\mathrm{m}$ altitude in mean difference $11.40 *$ (Variance ratio, $F=9.84, \mathrm{p}=0.001$ ) and $301-400 \mathrm{~m}$ altitude is significantly different at $401-500 \mathrm{~m}$ altitude with mean difference $7.95 *$ (Variance ratio, $\mathrm{F}=9.84, \mathrm{p}=0.006$ ).

\section{Soil fertility status based on altitude}

Mean sand, silt and clay percentage of all layers are observed $52.90 \%, 18.10 \%$ and $29.00 \%$, respectively at $201-300 \mathrm{~m}$ altitude followed by $60.00 \%, 20.00 \%$ and $20.00 \%$ at $401-500 \mathrm{~m}$ altitude, and $61.40 \%$, $19.00 \%$ and $19.60 \%$ at $301-400 \mathrm{~m}$ altitude. An average soil bulk density, soil organic matter, soil $\mathrm{pH}$, available phosphorus, exchangeable potassium and $\mathrm{CN}$ ratio are higher in middle altitude $(301-400 \mathrm{~m})$ followed by $401-$ $500 \mathrm{~m}$ altitude and least in 201-300 $\mathrm{m}$ altitude. An average total nitrogen percentage is higher in 201-300 m followed by $401-500 \mathrm{~m} \mathrm{301-400} \mathrm{m}$ altitude.

\section{Soil quality index in Kankali Community Forest}


The altitude wise SQI in different depths of soil in KCF with individual soil quality rating of physiochemical parameters are presented in Table 6. The SQI in surface layer in all altitudes reveal that higher, ranged from 0.54 to 0.64 (fair) qualities as compared to subsurface layer that is varied from 0.50 to 0.52 (fair) qualities. The SQI slightly decreases with increasing soil depths. An average SQI in KCF is found 0.55 (fair) up to $120 \mathrm{~cm}$ depth. The order of weighting index of mean soil parameters shows texture and NPK $(0.19)>\operatorname{SOC}(0.12)>\mathrm{pH}(0.05)$.

Table 6: Depth wise soil quality index with soil quality rating in KCF

\begin{tabular}{|c|c|c|c|c|c|c|c|c|c|c|}
\hline Strata & $\begin{array}{l}\text { Soil } \\
\text { depth } \\
\text { (m) }\end{array}$ & $\begin{array}{l}\text { Tex. } \\
\text { Rating }\end{array}$ & $\begin{array}{l}\text { Tex. } \\
\text { SQI }\end{array}$ & $\begin{array}{l}\mathrm{pH} \\
\text { rating }\end{array}$ & $\begin{array}{l}\text { pH } \\
\text { SQI }\end{array}$ & $\begin{array}{l}\text { SOC } \\
\text { rating }\end{array}$ & $\begin{array}{l}\text { SOC } \\
\text { SQI }\end{array}$ & $\begin{array}{l}\text { NPK } \\
\text { rating }\end{array}$ & $\begin{array}{l}\text { NPK } \\
\text { SQI }\end{array}$ & SQI \\
\hline \multirow{6}{*}{$201-300 \mathrm{~m}$} & $0-15$ & 1 & 0.2 & 0.4 & 0.04 & 0.4 & 0.16 & 0.8 & 0.24 & 0.64 \\
\hline & $15-30$ & 1 & 0.2 & 0.4 & 0.04 & 0.4 & 0.16 & 0.6 & 0.18 & 0.58 \\
\hline & $30-60$ & 1 & 0.2 & 0.6 & 0.06 & 0.2 & 0.08 & 0.6 & 0.18 & 0.52 \\
\hline & $60-90$ & 1 & 0.2 & 0.6 & 0.06 & 0.2 & 0.08 & 0.6 & 0.18 & 0.52 \\
\hline & $90-120$ & 1 & 0.2 & 0.4 & 0.04 & 0.2 & 0.08 & 0.6 & 0.18 & 0.5 \\
\hline & Average & 1 & 0.2 & 0.48 & 0.05 & 0.28 & 0.11 & 0.64 & 0.19 & 0.55 \\
\hline \multirow{6}{*}{$301-400 \mathrm{~m}$} & $0-15$ & 0.8 & 0.16 & 0.6 & 0.06 & 0.4 & 0.16 & 0.8 & 0.24 & 0.62 \\
\hline & $15-30$ & 0.8 & 0.16 & 0.6 & 0.06 & 0.4 & 0.16 & 0.6 & 0.18 & 0.56 \\
\hline & $30-60$ & 0.8 & 0.16 & 0.6 & 0.06 & 0.4 & 0.16 & 0.6 & 0.18 & 0.56 \\
\hline & $60-90$ & 1 & 0.2 & 0.6 & 0.06 & 0.2 & 0.16 & 0.6 & 0.18 & 0.6 \\
\hline & $90-120$ & 1 & 0.2 & 0.6 & 0.06 & 0.2 & 0.08 & 0.6 & 0.18 & 0.52 \\
\hline & Average & 0.88 & 0.18 & 0.6 & 0.06 & 0.32 & 0.14 & 0.64 & 0.19 & 0.57 \\
\hline \multirow{6}{*}{$401-500 \mathrm{~m}$} & $0-15$ & 0.8 & 0.16 & 0.4 & 0.04 & 0.4 & 0.16 & 0.6 & 0.18 & 0.54 \\
\hline & $15-30$ & 0.8 & 0.16 & 0.4 & 0.04 & 0.4 & 0.16 & 0.6 & 0.18 & 0.54 \\
\hline & $30-60$ & 1 & 0.2 & 0.4 & 0.04 & 0.2 & 0.08 & 0.6 & 0.18 & 0.5 \\
\hline & $60-90$ & 1 & 0.2 & 0.4 & 0.04 & 0.2 & 0.08 & 0.6 & 0.18 & 0.5 \\
\hline & $90-120$ & 1 & 0.2 & 0.4 & 0.04 & 0.2 & 0.08 & 0.6 & 0.18 & 0.5 \\
\hline & Average & 0.92 & 0.18 & 0.4 & 0.04 & 0.28 & 0.11 & 0.6 & 0.18 & 0.52 \\
\hline \multicolumn{2}{|c|}{ Average } & 0.93 & 0.19 & 0.49 & 0.05 & 0.29 & 0.12 & 0.63 & 0.19 & 0.55 \\
\hline
\end{tabular}

Source: Field survey 2016 
The weighting index of SOC appears in second place and NPK in first that may be due to the low contribution of organic matter. Tiwari (2006) reported the SQI as "poor" (0.45) of the forest land in Pokhre Khola watershed of Nepal. Bajracharyaet al. (2007) was reported 33\% as "fair", $20 \%$ as"poor", and the majority (47\%) as "good" quality from the forest soils of Nepal.

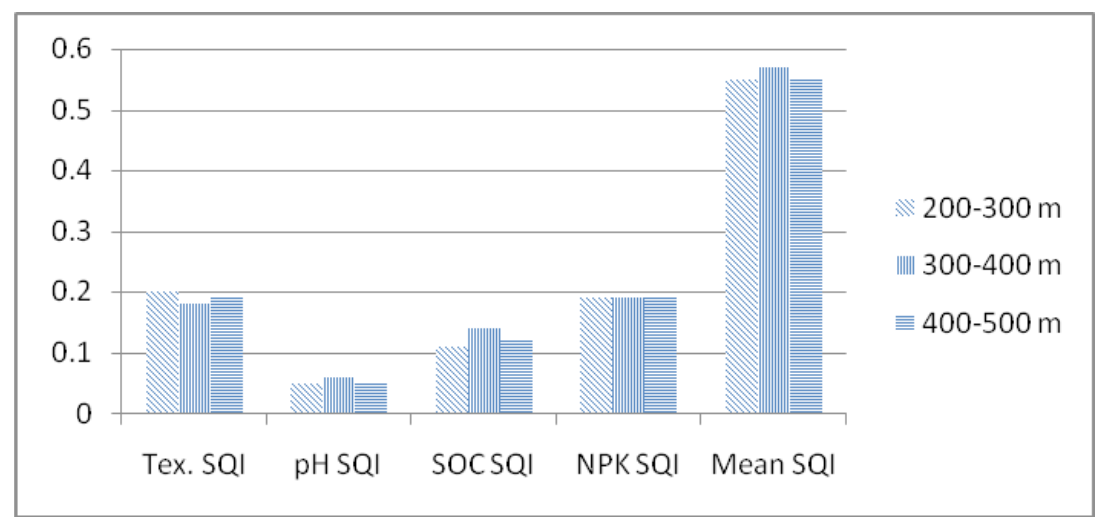

Figure 3: Comparison of soil quality rating and mean soil quality index

Larson and Pierce (1994) were reported that SOC was the single most imperative indicator of soil quality in the upper few centimeters of the soil. Wang et al.(2003) reported that SOC to be a key attribute of soil quality because it determines physical, chemical and biological soil properties. However, the weighting index in KCF (Table 6) indicates that all dynamic soil properties are important in determining the soil quality indices. $\mathrm{N}, \mathrm{P}$ and $\mathrm{K}$ are the most important parameters to determine the soil quality in this study because $\mathrm{N}$ shows high positive correlation in this forest $(>0.75)$ with SOC.

\section{CONCLUSION}

Seven physiochemical attributes of soil were undertaken to evaluate soil fertility and soil quality index in Kankali community forest. Overall soil fertility status and soil quality shows higher in middle altitude that is due to regeneration vegetation composition of the forest. Soil $\mathrm{pH}$, bulk density and available phosphorus shows statistically significant different with altitudinal gradient. Overall soil fertility rating was ranged from low to moderate and soil quality index as "fair" rating. It provides knowledge to maintain soil fertility and soil quality of the forest for better management. 
Regulation of Leaf litter collection and adoption of appropriate silvicultural operation help to increase the fertility status and site quality of Kankali community forest.

\section{REFERENCES}

Allison, F. A. (1973). Soil organic matter and its role in crop production. Amsterdam: Elsevier.

Bajracharya, R. M., Sitaula, B. K., Sharma, S. \& Jeng, A. (2007). Soil quality in the Nepalese context - An analytical review. Int. J. Eco. Env. Sci., 33(2-3):143-158.

Bajracharya, R.M., Sharma, S., Dahal, B.M., Sitaula, B. K. \& Jeng, A. (2006). Assessment of soil quality using physiochemical and biological indicators in a mid-hills watershed of Nepal. Climate Change Feature Archive. Bali, Indonesia.

Bhatnagar, H. P. (1965). Soils from different quality sal (S. robusta) forests of Uttar Pradesh. Trop. Ecol. 6: 56-62.

Binkley, D. and Vitousek, P. M. (1989). Soil nutrient availability. In: Pearey, R. W., J. Ehleringer, H. A., Mooney \& P. W. Rundel (eds.), Plant physiological ecology: Fieldmethods and instrumentation. London: Chapman and Hall, pp. 75-96.

Bouyoucos, C. J. (1962). Hydrometer method improved for making particle size analysis of soils. Agronomy Journal, 54: 464-465

Brady, N. C. (2000). The nature and properties of soils, Tenth edition. New Delhi: Prentice' Hall of India Private limited.

Chapin, F. S. H., Van Cleve, K. \& Vitousek, P. M. (1986). The nature of nutrient limitation in plant communities. Am. Nat., 127:148-158.

Chapman, J. L. \& Reiss, M. J. (1992). Ecology: Principles and applications. Cambridge: Cambridge University Press.

Gautam, T. P. \& Mandal, T. N. (2013).Soil characteristics in moist tropical forest of Sunsari district, Nepal. Nepal J. Sci. Tech., 14 (1): 35-40

Gupta, M. K. \& Sharma, S. D. (2009). Effect of tree plantation on soil properties, profile morphology and productivity index II. Poplar in Yamunanagar district of Haryana. Ann. For, 17(1): 53-70.

Jackson, M. L. (1967). Soil chemical analysis. New Delhi: Prentice Hall of India Private Limited, pp. 38-82. 
Johnston, A. E. (1986). Soil organic matter, effects on soil and crops. Soil Use Manag. 2: 97-105.

Joshi, C. S., Singh, R. P. \& Rao, B. P. (1999).Pattern of leaf litter decomposition in forest plantation of Tarai region in U.P India. Tro. Eco., 40 (1): 99-108.

Karlen, D.L., Mausbach, M.J., Doan, J.W., Cline, R.G., Harris, R.F. \& Schuman, G.E. (1997). Soil quality: a concept, definition and framework for evaluation. Soil Sci. Soc. Am. J. 61: 4-10.

Kharal, S., Khanal, B. R. \& Pandey, D. (2018).Assessment of Soil Fertility under Different Land-Use Systems in Dhading District of Nepal. Soil System. 57 (2): 1-8

Kononova, M. M. (1966). Soil organic matter. London: Pergamon Press Ltd.

Larson, W. E. \& Pierce, F. J. (1994). The dynamic of soil quality as a measure of sustainable management. In: Doran, J. W. et al. (eds.). Defining Soil Quality for a Sustainable Environment. ASA and SSSA, Madison, WI, pp. 37-51.

LRMP. (1986). Land system report: The soil landscapes of Nepal. Kenting earth sciences Ltd, Land Resources Mapping Project, pp. 1-140.

NARC. (1999). Annual report 1998/99. Kathmandu: Nepal Agricultural Research Council, Soil Science Division.

Paudel, S. \& Sah, J. (2003). Physiochemical characteristics of soil in tropical sal (Shorearobusta Gaertn.) forests in eastern Nepal. Him. J. Sci., 1(2): 107-110.

Ranabhat, S., Awasthi, K. D. \& Malla, R. (2008).Carbon sequestration potential of Alnusnepalensis in the mid hill of Nepal: A case study from Kaski district. Banko Janakari, 18(2): 3-9.

Shah, R. (1999). Soils: Their problems and management. In: Majupuria T. C. (eds.), Nepal: Nature's paradise. Kathmandu: Hillside Press Ltd, pp. 8- 64.

Sharma, R. P. (2013). Status of soil nutrients and its relation with rock types and soil properties in the Kankali (Chitwan) and Tibrekot (Kaski) Community Forests, western Nepal. J. Nep. Geo. Soc., 46: 211216. 
14 ANALYTICAL STUDY ON FERTILITY STATUS AND SOIL QUALITY ...

Tiwari, K. R., Sitaula, K. B., Borresen, T. \& Bajracharya, S. M. (2006). An assessment of soil quality in PokhareKhola watershed of the Middle Mountains in Nepal. J. Food, Agri. Env., 4(3): 276- 283.

Walkley, A. (1947). An examination of methods for determining organic carbon and nitrogen in soils. J. Agri. Sci., 25: 598-609.

Wang, J., Fu, B., Qiu, Y. \& Chen, L. (2003). Analysis on soil nutrient characteristics for sustainable land use in Danangou catchment of the Loess Plateau, China. Catena, 54: 17-29. 